\title{
空間固有モードを用いた境界要素法による電磁界解析
}

$\begin{array}{llllllll}\text { 正員 } & \text { 坪 } & \text { 井 } & & \text { 始 } & \text { (福 } & \text { 山 } & \text { 大) } \\ \text { 正 } & \text { 員 } & \text { 藤 } & & \text { 督 } & \text { (富士電機総研) } \\ \text { 准 } & \text { 員 桜 } & \text { 井 } & \text { 章 } & \text { 広 } & \text { (岡 } & \text { 山 } & \text { 大) }\end{array}$

\section{Electromagnetic Field Analysis by Boundary Element Method Using Spatial Eigenmodes}

\begin{abstract}
Hajime Tsuboi, Member (Fukuyama University), Tadashi Naito, Member (Fuji Electric
\end{abstract} Corporate R \& D, Ltd.), Akihiro Sakurai, Associate (Okayama University)

In this paper, a boundary element method using spatial eigenmodes for electromagnetic field analysis is proposed. Mapping the computation model with rotational symmetries, reflective symmetries or rotational symmetries including reflective symmetries to a group of spatial eigenmodes, the equivalent reduced models are obtained. In the method, the applicability becomes wide because arbitrary external source terms can be chosen. Furthermore, in a model including asymmetry regions, a new method, which can save the merit of the symmetries, is proposed. Finally, the validity of the proposed method is proved by numerical simulations.

キーワード：空間固有モード, 境界要素法, 電磁界解析, ブロック対角化法

\section{1.まえがき}

電磁界解析に打いては対象が空間的な対称性をもつ 場合が多くこれを利用した計算モデルの縮約が有限 要素法(1)(2) や境界要素法(3) で行われている。文献(1) では, いわゆる回転機の周期境界条件として回転対称 性を考虑し, 計算モデルを 1 極分に縮小する方法が述 べられているが，外部印加項の起磁力が $N$ 極と $S$ 極 で極性が反転する特定のモデルにしか適用できない。 文献 (2)では, 回転対称性のある計算モデルに対して ラグランジュの未定乗数法を用いて対称部分の境界の 接続条件を取扱う手法が述べられている。この手法て は，形状に回転対称性があれば，強制電流のような外 部印加条件は任意であるが，鏡映対称性が扱えないと 共に，ラグランジュの未定乗数法による接続条件の取 扱いが繁雑である。また，有限要素法では回転対称軸 に変数を設けられないため, モデルを中空近似する必 要があるので, 計算精度の低下が懸念される。文献 (3.)では, 上下対称な角柱領域について境界要素モデ ルの縮約法が検討されているが，外部印加項に任意性
がない。

そこで著者らは, 境界要素法では要素分割が境界面 のみであるため, 有限要素法で必要となる中空近似や ラグランジュの末定㝜数法による対称面の接続条件を 陽に用いることが不要となることに着目し，空間対称 性をもつ計算モデルで任意の外部印加項が取扱える統 一的な解析法と計算モデルの縮約法について述べる。

提案する手法においては，回転対称の問題では対称 座標法による変数変換 ${ }^{\left({ }^{2}\right)}$ を, 鏡映対称の問題では二 相回路理論( ${ }^{(5)}$ を用いた変数変換を適用し, 計算モデ ルを幾つかの縮約されたモデルに変換する。このと き, 変数変換により, 計算モデルは空間的な各固有モ ードごとに分解され，最終結果は固有モードの合成 （線形結合）によって得られることを示す。また，境 界要素法の最終連立方程式の係数行列の性質について 検討し, 空間固有モードを用いた解析が, 計算モデル の縮約に効果的であることを示す。これにより，境界 要素法においては，回転あるいは鏡映対称の計算モデ ルの統一的な取扱による縮約が可能となる。この場 合，係数行列は変数変換によってプロック対角化され 
るため，本手法をブロック対角化法と呼ぶ。

一方, 空間対称性を前提とするブロック対角化法 は，計算モデルの極く一部でも対称性が成立しない場 合には適用できず，その特徵が十分に生かされないの で，同法の適用範囲を拡張するため，全体での対称性 が成立しなくても，部分的に対称性を有する場合に は，対象を対称部と非対称部に分け，前者にのみに変 数変換を適用する手法も新たに提案する。この場合， 連立方程式の係数行列が緑付プロック対角化されるた め, ブロック対角化法の利点を保存できる。

本論文は，まず境界要素法の係数行列の性質につい て述べ，次いで境界要素法に扔ける空間固有モードを 用いた解析手法の適用法について，回転対称，鏡映対 称，鏡映対称を含む回転対称の計算モデルの順に述べ ている。また，計算モデルの縮約という観点から，そ の効果について述べている。更に，縁付ブロック対角 化法について，その理論，適用法および効果について 述べている。

\section{2. 境界要素法の係数行列の性質}

ベクトル変数である磁束密度 $\boldsymbol{B}$ を用いた境界要素 法扔よびスカラポテンシャル $\varphi$ を用いた境界要素法 の計算点 $i$ における基本式は, 境界面 $S$ に関する境 界積分によってそれぞれ次の上うに表される(6)(7)。

$$
\begin{aligned}
\boldsymbol{B}_{i} / 2= & \iint_{S}\left\{-\left(\boldsymbol{B} \cdot \boldsymbol{n}^{\prime}\right) \nabla \phi+\left(\boldsymbol{B} \times \boldsymbol{n}^{\prime}\right) \times \nabla \phi\right. \\
& \left.+j k^{2} / \omega\left(\boldsymbol{E} \times \boldsymbol{n}^{\prime}\right) \phi\right\} d S+\boldsymbol{B}_{0} \cdots \cdots \\
\varphi_{i} /= & 2 \iint_{S}\left(\phi \nabla \varphi \cdot \boldsymbol{n}^{\prime}-\varphi D \phi \cdot \boldsymbol{n}^{\prime}\right) d S+\varphi_{0}
\end{aligned}
$$

ここで， $\phi$ : 基本解， $n^{\prime}:$ ソースのある境界 面上の单位法線ベクトル, $\boldsymbol{E}:$ 電界, $k:$ 波 数（複素誘電率 $\epsilon$ および透磁率 $\mu$ を用いて， $k=\omega \sqrt{\varepsilon \mu}$ で与えられる), $\omega:$ 角周波数, $\boldsymbol{B}_{0}, \varphi_{0}$ : 外部ソースの影響

（1）（2)式では，基本的には基本解 $\phi$ とそのこう

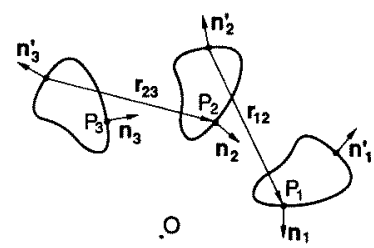

図 1 係数行列計算のためのベクトル

Fig. 1. Vectors for coefficient matrix calculation.
配 $D \phi$ を計算し， $\boldsymbol{n}^{\prime}$ とのベクトル演算を行う。基本 解 $\phi$ は距離 $r$ の関数であるので, 境界要素法の係数 行列の要素は計算点からソース点へ向かうべクトル $\boldsymbol{r}$ および $\boldsymbol{r}$ と $\boldsymbol{n}^{\prime}$ のベクトル演算などによって求められ る。また，(1)，(2)式の計算值は境界面の位置関係 によってのみ決まるため, 係数行列の計算佔は境界面 の相対的な位置関係が同じであれば同じ值となる。

例として, 図 1 に示すモデルで $\omega=0$ の三次元静磁 界解析を行う場合には， $\phi=1 /(4 \pi r)$ であるので， $\nabla \phi$ $=-\boldsymbol{r} /\left(4 \pi r^{3}\right)$ となり， $\boldsymbol{r}_{12}$ と $\boldsymbol{n}_{2}^{\prime}$ および $\boldsymbol{r}_{23}$ と $n_{3}^{\prime}$ のよ うに相対的な位置関係が同じであれば，（1）式の計算 值は同一となる。更に，係数行列の計算で法線方向成 分の係数を考えると，計算点の法線べクトル $\boldsymbol{n}$ との 内積をとって係数を求めるため, 前述のべクトル $\boldsymbol{n}_{1}$ と $n_{2}$ がそれぞれ $\boldsymbol{r}_{12}$ と $\boldsymbol{n}_{2}^{\prime}$ おひび $\boldsymbol{r}_{23}$ と $\boldsymbol{n}_{3}^{\prime}$ と同じ位置 関係にあれば係数行列の要素は同じ值になる。接線成 分の係数は $\boldsymbol{n}$ との外積をとって計算するが，同様の 議論が成立し, 更に, 渦電流問題や電磁界問題でも同 様である。また，(2)式の場合も同様である。このこ とは, 境界要素法の係数行列が座標系に関係なく決ま ることを示している。

また，境界要素法の最終連立方程式は一般に次のよ うになる。

$$
[S]\{A\}=\{J\}
$$

ここで, $\{S]$ : 係数行列, $\{A\}:$ 末知変数べ

クトル, $\{J\}:$ 外部印加ベクトル

\section{3. 境界要素法へのフロック対角化法の適用}

〈3・1〉回転対称の場合 図 2 に回転対称の計算 モデルの例を示す。同図は三次元モデルを $\boldsymbol{z}$ 軸から みて， $x-y$ 平面に投影している。同図に示すように， 対称性に従い分割された部分をセグメントと呼び，反 時計方向に順次，セグメント $1,2, \cdots, N$ と呼ぶ。

図 2 のモデルに境界要素法を直接適用したとき，得 られる係数行列 [ $\left.S_{s}\right]$ 快次のように与えられる。

$$
\left[S_{S}\right]=\left[\begin{array}{cccc}
S & S_{1} & \cdots & S_{N-1} \\
S_{N-1} & \ddots & \ddots & \\
& \ddots & S & S_{1-1} \\
S_{1} & \cdots & S_{N-1} & S_{-1}
\end{array}\right]
$$

上式の $\left[S_{s}\right]$ は，前章で述べたように境界要素法の係 数は計算点とソース点の相対的な位置関係で決まるた め，セグメント単位の $S, S_{1}, \cdots, S_{n-1}$ が巡回配置され て抢り，[Ss]の作成はセグメント 1 に関する係数の みの作成ですむことが知られる。従って，セグメント 数 $N$ 回転対称モデルでは, 係数行列作成の計算量 


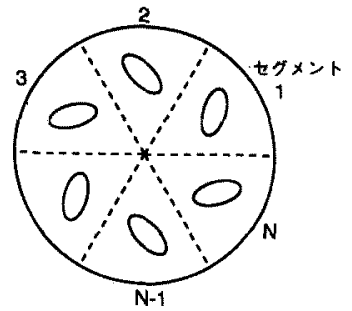

図 2 回転対称モデル

Fig. 2. Rotational symmetry model.

は $1 / N$ に軽減される。ここでは，説明を容易にする ため各セグメントの末知変数はそれぞれ一変数と仮定 する。上式を用いて，（3)式は次のようになる。

$$
\begin{aligned}
{[S[\boldsymbol{E}]} & +S_{N / 2}\left[K_{R}\right]^{N / 2}+\sum_{m=1}^{M}\left(S_{m}\left[K_{R}\right]^{m}\right. \\
& \left.\left.+S_{N-m}\left[K_{R}\right]^{N-m}\right)\right]\{A\}=\{J\}
\end{aligned}
$$

ただし， $[\boldsymbol{E}\rfloor は$ 単位行列で， $M$ は次式で与えられる。

$$
M=\left\{\begin{array}{ll}
(N-1) / 2 & : N \text { が奇数の場合 } \\
(N-2) / 2 & : N \text { が偶数の場合 }
\end{array}\right\}
$$

また，回転対称性を表す $N$ 次巡回行列 $\left[K_{R}\right]$ は次式で 与えられる。

$$
\left[K_{R}\right]=\left[\begin{array}{ccccccc} 
& 1 & & & & & \\
& & 1 & \ddots & & 0 & \\
& & & \ddots & \ddots & & \\
& & & & \ddots & \ddots & \\
& 0 & & & & 1
\end{array}\right]
$$

上式に $N$ 相の対称座標法を適用すれば，対称分は次 のように係数行列がブロック対角化され，互いに独立 となる。

$$
[C]^{-1}\left[S_{s}\right][C]\{F\}=\{I\}
$$
こで

$$
\begin{gathered}
{[C]^{-1}\left[S_{s}\right][C]=\left[\begin{array}{cccc}
U_{0} & & 0 \\
& U_{1} & \\
& & \ddots & \\
& & \ddots & \\
& & & U_{N-1}
\end{array}\right]} \\
{[C]=\left[\begin{array}{lllll}
1 & 1 & \cdots & 1 \\
1 & a^{-1} & \cdots & a^{-(N-1)} \\
1 & a^{-2} & \cdots & a^{-2(N-1)} \\
& \cdots & \cdots & \\
1 & a^{-(N-1)} & \cdots & a^{-(N-1)(N-1)}
\end{array}\right]}
\end{gathered}
$$

$$
\begin{aligned}
& \{F\}=[C]^{-1}\{A\} \\
& \{I\}=[C]^{-1}\{J\}
\end{aligned}
$$

ただし，

$$
a=\varepsilon^{j 2 \pi / N}
$$

このとき，(12)式の外部印加項 $\{J\}$ には何の制約も課 されて招らず，\{J\}従って外部印加項は任意のことが 知られる。また各刘称分の係数行列は次のように表さ れる。

$$
\begin{aligned}
U_{k}= & {\left[S+(-1)^{k} S_{N / 2}\right.} \\
& \left.+\sum_{m=1}^{M}\left(a^{-k m} S_{m}+a^{k m} S_{N-m}\right)\right]
\end{aligned}
$$

従って，形式的にマトリックス表示すれば，解くべき 連立方程式は $N$ 組の次の方程式である。

$$
\left[U_{k}\right]\left\{F_{k}\right\}=\left\{I_{k}\right\}
$$

上式は $k=1$ より各相を順次解けばよいため, 同時に 必要とされる記憶容量は $[S],\left[S_{1}\right], \cdots,\left[S_{N-1}\right]$ と $\left[U_{k}\right]$ なので, $(N+1) / N^{2}$ に低减される。

また， $\{A\}$ は解かれた $\{F\}$ から次式によって求め られる。

$$
\{A\}=[C]\{F\}
$$

以上により，回転対称性を有する計算モデルでは， (11)，(12)式による変数変換を用いて空間的な固有モ ードに分解され，各モードごとに(14)式で解を求め, 上式の逆変換によって最終的な解が得られることを示 した。また，(14)式は全末知数の $1 / N$ の小行列とな っているため, 結果的に計算モデルの縮約が行われた ことになる。このとき，(12)式の変換で，外部印加項 $\left\{I_{k}\right\}$ が零になるモードがあればそのモードについては (14)式を解く必要がなくなり, 計算時間は短縮され る。

〈3.2〉鏡映対称の場合 図 3（a）のモデルは鏡 映対称でありここれを利用すればモデルは $1 / 2$ にでき る(3)。同図に示寸ように，鏡映面に対して任意の一方 のセグメントを $r(\mathrm{real})$, 他方をセグメント $i$ (imaginary) と呼离。

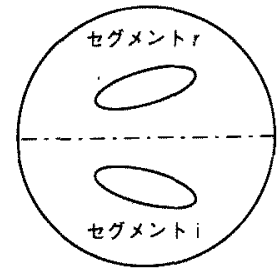

(a) 鏡映对称

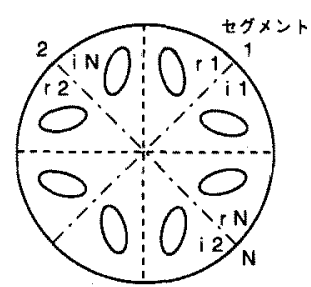

(b) 回軾対称を含を鏡映詨称
図 3 鏡映対称モデル

Fig. 3. Reflective symmetry model. 
二つのセグメントが鏡映対称の場合，セグメント $r$ に右手，他方に左手座標系を適用すれば，得られる方 程式は次のように書ける。

$$
\left[\begin{array}{ll}
{\left[S_{s}\right]} & \left\{S_{M}\right] \\
{\left[S_{M}\right]} & {\left[S_{s}\right]}
\end{array}\right]\left\{\begin{array}{l}
\left\{A_{r}\right\} \\
\left\{A_{i}\right\}
\end{array}\right\}=\left\{\begin{array}{l}
\left\{J_{r}\right\} \\
\left\{J_{i}\right\}
\end{array}\right\}
$$

上式に二相時の対称座標法である二相回路理論による 変換を適用すると, 次式が得られる。

$$
\left.\begin{array}{l}
\left\{\left[S_{S}\right]+\left[S_{M}\right]\right\}\left\{A_{I}\right\}=\left\{J_{I}\right\} \\
{\left[\left[S_{M}\right]-\left[S_{S}\right]\right)\left\{A_{I I}\right\}=\left\{J_{I I}\right\}}
\end{array}\right\}
$$

ここで

$$
\left.\begin{array}{l}
\left\{A_{I}\right\}=\left\{A_{r}\right\}+\left\{A_{i}\right\} \\
\left\{A_{I l}\right\}=\left\{A_{r}\right\}-\left\{A_{i}\right\}
\end{array}\right\}
$$

添字 I , II は第一, 第二回路を表している。(16)式よ $\eta ，$ 第一，第二回路は独立となることがわかる。

(17)式で得られた解から， $\left\{A_{r}\right\},\left\{A_{i}\right\}$ は次式によっ て求められる。

$$
\left.\begin{array}{l}
\left\{A_{r}\right\}=\left(\left\{A_{l}\right\}+\left\{A_{I I}\right\}\right) / 2 \\
\left\{A_{i}\right\}=\left(\left\{A_{l}\right\}-\left\{A_{H I}\right\}\right) / 2
\end{array}\right\}
$$

以上により，鏡映対称性がある場合にも，二つのモ 一ドに分解して解析できることがわかる。またこれに より，モデルの縮約が可能なことがわかった。また， この場合には明らかに，(17)式より係数行列の作成の 計算量は $1 / 2$ になることが知られる。

$\langle 3 \cdot 3\rangle$ 回転対称を含む鏡映対称の場合 回転対 称を含む鏡映対称の場合は，(16)式の行列 $\left[S_{M}\right]$ 《次 のように与えられる。

$$
\left[S_{M}\right]=\left[\begin{array}{llll}
S_{1}^{\prime} & S_{2}^{\prime} & \cdots & S_{N}^{\prime} \\
S_{2}^{\prime} & \cdots & S_{N}^{\prime} & S_{1}^{\prime} \\
& \therefore & . & \\
S_{N}^{\prime} & S_{1}^{\prime} & \cdots & S_{N-1}^{\prime}
\end{array}\right]
$$

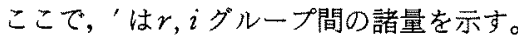

まず，二相回路理論による変換を適用すると，(17) 式が得られる。次に, 回転対称性に対して対称座標法 を適用するが，説明を容易にするため，行列 [ $\left.S_{M}\right]$ を 次のよう変形する。

$$
\left[S_{M}\right]=\left[K_{D}\right]\left(\sum_{n=1}^{N} S_{n}^{\prime}\left[K_{R}\right]^{n}\right)
$$

ただし，鏡映対称性を示す行列 $\left(K_{D}\right)$ は，次式で与え られる。

$$
\left\lceil K_{D}\right]=\left[\begin{array}{ccc}
0 & & 1 \\
. . & . & 1 \\
1 & & 0
\end{array}\right]
$$

（22）式に対称座標法を適用すれば，次のようになる。 $[C]^{-1}\left[S_{M}\right][C]$

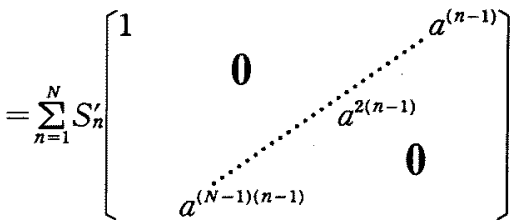

(24)

従って，(17)式は対称座標法により次のようになる。

(i) 第一回路

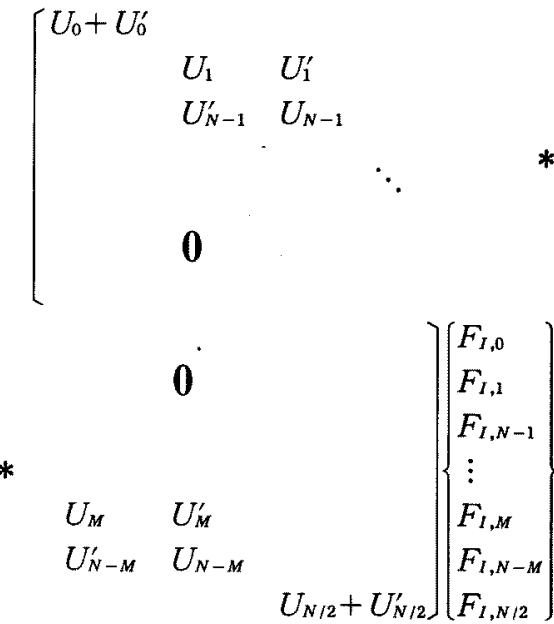

$$
=\left\{\begin{array}{l}
I_{I, 0} \\
I_{I, 1} \\
I_{I, N-1} \\
\vdots \\
I_{I, M} \\
I_{I, N-M} \\
I_{I, N / 2}
\end{array}\right\}
$$

（ii） 第二回路

$$
\left[\begin{array}{c}
U_{0}-U_{0}^{\prime} \\
\\
\end{array}\right.
$$




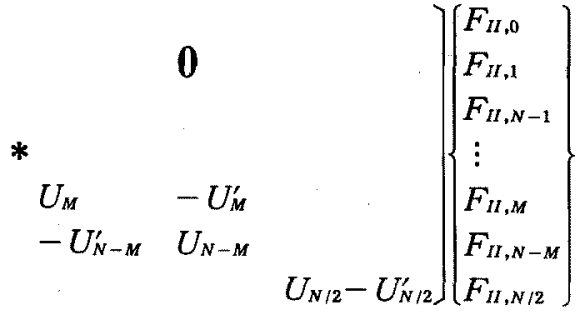

$$
=\left\{\begin{array}{l}
I_{I I, 0} \\
I_{I I, 1} \\
I_{I I, N-1} \\
\vdots \\
I_{I I, M} \\
I_{I I, N-M} \\
I_{I I, N / 2}
\end{array}\right\}
$$

ただし

$$
U_{m}^{\prime}=\sum_{n=1}^{N} a^{m(n-1)} S_{n}^{\prime}
$$

(25)，(26)式より複素共役な第 $m$ 相と第 $(N-m)$ 相 は連成するが，その他の相とは独立なことがわかる。

この場合も空間的な各固有モードごとに分解して解 析でることがわかった。縮約の効果としては, 計算 規模は回転対称時と同一となるが，係数行列 [S] の次 元が $1 / 2$ であるため, その作成の計算量は $1 / 2 N$ に軽 減される。

〈3.4〉 緑付ブロック対角化法 前述のブロック 対角化法はモデル全体で空間対称性が成立しなければ ならず，計算モデルに非対称部分があると同法の特長 が生かされない。そこで，同法の適用範囲を挔大する 手法を提案する。

図 4 に回転対称モデルに非対称部が付加された例を 示す。同図より，連立方程式として次式が得られる。 ここでは，簡単のため非対称部は変数 1 として説明を
行う。

$$
\left[\begin{array}{ll}
\left\{S_{S}\right] & \left\{S_{S A}\right. \\
\left\{S_{A S}\right\}^{T} & S_{A}
\end{array}\right]\left\{\begin{array}{c}
\left\{A_{S}\right\} \\
A_{A}
\end{array}\right\}=\left\{\begin{array}{c}
\left\{J_{S}\right\} \\
J_{A}
\end{array}\right\}
$$

ただし, 添字 $S$ は対称部, $A$ は非対称部を示し, $\left\{S_{S A}\right\},\left\{S_{A S}\right\}^{T}$ は対称部々非対称部の関係を示す係数部 である。対称性を利用するため，回転対称部に $N$ 相 対称座標法を適用すれば， $\left[S_{s}\right]$ は(13)式で示される ようにブロック対角行列となるので，上式は次のよう になる。
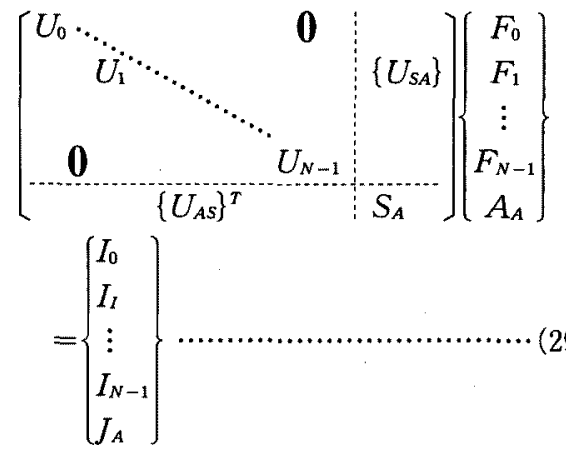

ただし，

$$
\left\{U_{S A}\right\}=[C]^{-1}\left\{S_{S A}\right\}
$$

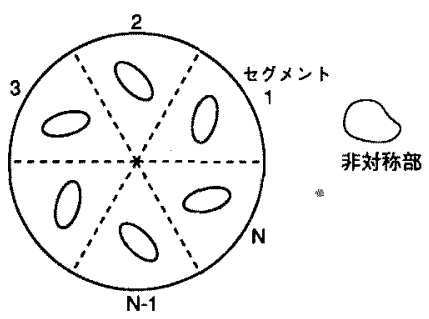

図 4 部分対称モデル

Fig. 4. Partial symmetry model.

表 1 計算時間の隇少率

Table 1. Reduction ratios of calculating time.

\begin{tabular}{l|c|c|c}
\hline 対 称性 & 非対称部 & 係数行列作成 & ガウスの消去法 \\
\hline 回転 & 無 & $1 / N$ & $1 / N^{2}$ \\
\hline \multirow{2}{*}{ 回転+鏡映 } & \multirow{2}{*}{ 無 } & $1 /(2 N)$ & $\frac{4 N-3}{4 N^{3}}(N:$ 奇数 $)$ \\
\hline \multirow{2}{*}{ 回転 } & 有 & $\frac{(1-\varepsilon)^{2}}{N}+\varepsilon(2-\varepsilon)$ & $\frac{(1-\varepsilon)^{3}}{N^{3}}+\frac{3(1-\varepsilon)^{2} \varepsilon}{N}+3(1-\varepsilon) \varepsilon+\varepsilon^{3}$ \\
\hline \multirow{2}{*}{ 回転+鏡映 } & 有 & $\frac{(1-\varepsilon)^{2}}{2 N}+\varepsilon(2-\varepsilon)$ & $\frac{(1-\varepsilon)^{3}(4 N-3)}{4 N^{3}}+\frac{3(1-\varepsilon)^{2} \varepsilon(4 N-3)}{4 N^{2}}+3(1-\varepsilon) \varepsilon+\varepsilon^{3}(N:$ 奇数) \\
& & $\frac{(1-\varepsilon)^{3}(2 N-3)}{2 N^{3}}+\frac{3(1-\varepsilon)^{2} \varepsilon(2 N-3)}{2 N^{2}}+3(1-\varepsilon) \varepsilon+\varepsilon^{3}(N:$ 偶数) \\
\hline
\end{tabular}




$$
\left\{U_{A S}\right\}^{r}=\left\{S_{A S}\right\}^{r}[C]
$$

上式の係数行列は緑付ブロック対角行列である。これ を利用すれば計算量の軽滅が可能となり, 部算モデル の縮約という観点から効果的である。

〈3.5〉空間的固有モードを用いた手法の計算時間 低減率境界要素法においては未知数の数を $n$ と

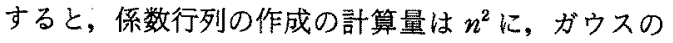
消去法の計算量は $n^{3}$ に比例するため, 空間的な固有 モードを用いた場合の縮約の効果は大きい。表 1 k全 ての相の外部印加項が非零の場合の計算量減少率を比 較揭示する。同表内に記載された記号 $\varepsilon$ は, 全変数 中に占める非対称部に属する変数の割合である。同表 より, 滅少効果の大なることが知られる。また, 同表 は対称性適用の基準となり, 特に非刘称部を有する場 合には効果的な対称性導入の検討が必要となる。

\section{4. 適用例}

本論文で提案した空間固有モードを用いた境界要素 法の計算結果の妥当性および計算モデルの縮約の効果 を確認するために，二次元拉よび三次元モデルの渦電 流解析を行った。

〈4・1〉 三心ケーフルモデル 図 5 に示す三心ケ ーブルモデルの二次元渦電流解析をべクトルポテンシ ヤルを用いて行った。同モデルは，回転対称を含む鏡 映対称のモデルで，解析領域は $1 / 6$ 領域に縮約され る。このとき， $N=3$ とした(12)式によって，三つの 相の外部印加項は次のように対称分に分解される。

$$
\left.\begin{array}{rl}
\nabla \phi_{0} & =\left(\nabla \phi_{a}+\nabla^{\prime \prime} \phi_{b}+\nabla \phi_{c}\right) / 3=\cos (\omega t) \\
\nabla \phi_{1} & =\left(\nabla \phi_{a}+\varepsilon^{-j 2 \pi / 3} \nabla \phi_{b}+\varepsilon^{j 2 \pi / 3} \nabla \phi_{c}\right) / 3 \\
& =\cos (\omega t) \\
\nabla \phi_{2} & =\left(\nabla \phi_{a}+\varepsilon^{-j 2 \pi / 3} \nabla \phi_{b}+\varepsilon^{j 2 \pi / 3} \nabla \phi_{c}\right) / 3 \\
& =\cos (\omega t)
\end{array}\right\}
$$

図6に同モデルの印加電圧の零相，正相（第一相）,

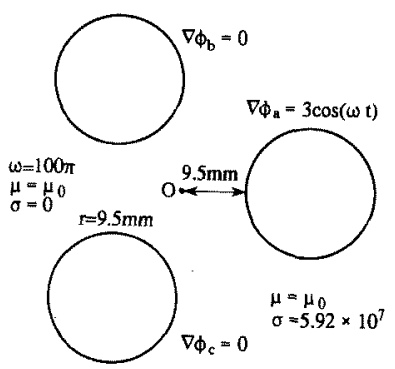

図 5 三心ケーブルモデル

Fig. 5. Three-core cable model.
逆相（第二相）の計算結果を等ポテンシャル線で示 す。零相磁束は回転中心を通過せず，正相と逆相磁束 は相回転が逆となり，物理的に妥当なものである。 た, これらの計算結果の合成逆変換を行って得られ た，図 5 に示す条件の計算結果を図 7 に示す。対称性 を導入した場合と全体を解析した場合の計算結果は一 致しそれれそれの場合の計算時間を表 2 に示す。同表 よりフブロック対角化法を用いた場合に大幅に計算時
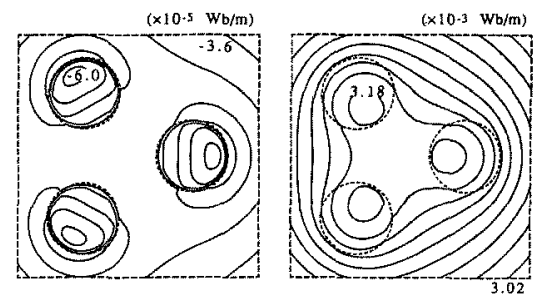

(a) 零相
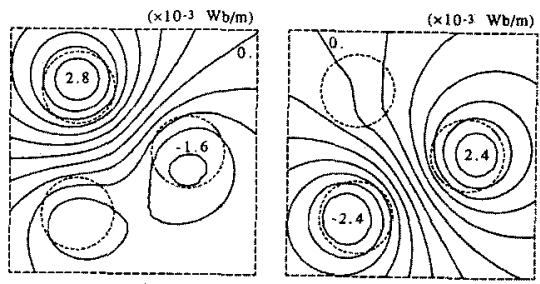

(b) 正暞

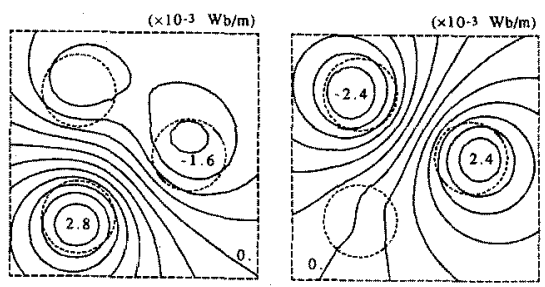

(c) 逆相

(i) 実部

(ii)，盛部

図 6 空間固有モードの計算結果

Fig. 6. Results of the spatial eigenmodes.

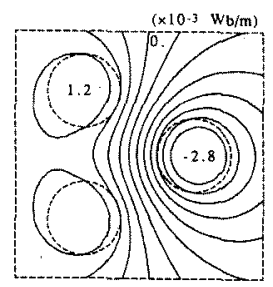

（a）実部

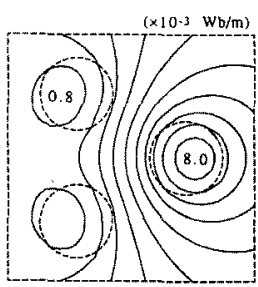

(b) 觑部
図 7 三心ケーブルモデルの計算結果 Fig. 7. Results of the three-core cable model. 
表 2 三心ケーブルモデルの計算結果

Table 2. Comparison of the calculating times for the three-core cable model.

(単位: 秒)

\begin{tabular}{l|c|c|c}
\hline \multirow{2}{*}{ 対称性 } & \multirow{2}{*}{ 末知数 } & \multicolumn{2}{|c}{ 計算内容 } \\
\cline { 3 - 4 } & & 倸数行列作成 & ガウス消去法 \\
\hline 無視 & 240 & 133.70 & 10.59 \\
\hline 回転 & 80 & 44.73 & 1.15 \\
\hline 回転十鏡映 & 40 & 22.41 & 0.82 \\
\hline
\end{tabular}

使用計算機：NEC ACOS-2010(48 MIPS)

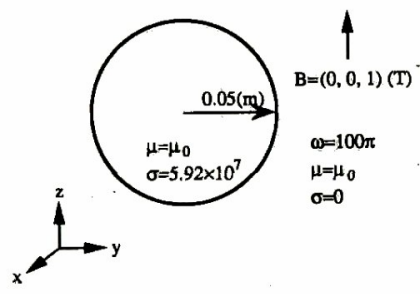

図 8 導体球モデル

Fig. 8. Conducting sphere model.
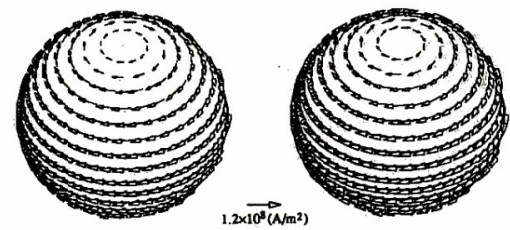

（a）全モテル(実部)

（b）全モデル(虚部)
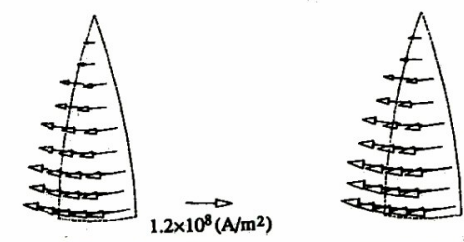

(c) 縮約モデル(実部)

(d）縮約モデル(虚部)

図 9 導体球モデル計算結果

Fig. 9. Results for the conducting sphere model.

間が軽減されていることが確認できる。

〈4・2〉導体球モデル 三次元モデルで理論解(8) の得られるモデルとして, 図 8 に示す導体球モデルを 選び, 磁束密度と電界の強さを末知変数とする境界要 素法で渦電流解析を行った。図 9 に全体を解析した場 合と周方向に $1 / 24$ に分割して回転対称性を導入し, 更に上下の鏡映対称性導入したブロック対角化法を用 いた場合の計算結果を示す。両者はよく一致し, 両者
表 3 導体球モデルの計算時間の比較

Table 3. Comparison of the calculating times for the conducting sphere model.

(単位：秒)

\begin{tabular}{l|r|r|c}
\hline \multirow{2}{*}{ 対称性 } & \multirow{2}{*}{ 未知数 } & \multicolumn{2}{|c}{ 計算内容 } \\
\cline { 3 - 4 } & & 係数行列作成 & ガウス消去法 \\
\hline 全球 & 3,600 & 127.84 & $1,686.34$ \\
\hline $1 / 24$ 球 & 150 & 5.48 & 0.08 \\
\hline \multicolumn{3}{|c}{ 使用計算機 : NEC SX-1 E(285 MFLOPS) }
\end{tabular}

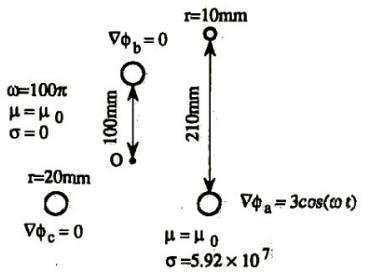

図 10 非対称部を含む三心ケーブルモデル Fig. 10. Three-core cable including an asymmetric part.

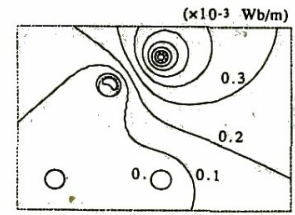

(a) 実部

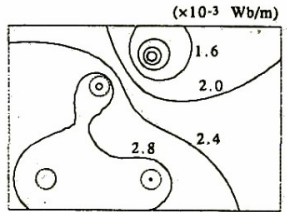

(b)觑部
図 11 非対称部を含む場合の計算結果 Fig. 11. Results for the model including asymmetric part.

表 4 非対称部を含を場合の計算時間の比較 Table 4. Comparison of the calculating times for the model including asymmetric part.

(単位：秒)

\begin{tabular}{|c|c|c|}
\hline \multirow{2}{*}{ 対称性 } & \multicolumn{2}{|c|}{ 計算内容 } \\
\hline & 係数行列作成 & ガウス消去法 \\
\hline 無視 & 50.32 & 0.56 \\
\hline 縁付として考虐 & 19.64 & 0.12 \\
\hline
\end{tabular}

とも最大計算誤差は $2.5 \%$ 以内であった。また, 計算 時間の比較を表 3 に示す。

〈4・3〉 非対称部を含む三心ケーブルモデル

非対称部が付加された三心ケーブルモデルを図 10 に示す。また，図 11 に計算結果を示す。表 4 に全体 を解析した場合と緑付きブロック対角化法を用いた場 
合の計算時間の比較を示す。この場合, 非対称部の未 知数が 24 , 対称部全体のそれが 120 であるが，縁付 きブロック対角化法の導入による計算時間の低減効果 が顕著である。

\section{5. むすび}

以上，境界要素法における空間固有モードを用いた 電磁界解析法について述べた。ここで提案した手法 は, 二次元問題および三次元問題に適用可能であり, 得られた成果を列記すれば，次のようである。

（1）境界要素法において計算モデルを空間固有モ ード群に投影することにより，大幅に計算時間と記憶 容量を軽減できることを理論的に示した。

（2）提案した手法で用いる変数変換は線形かつ 1 対 1 対応で, 何らの近似も行っていないため, 変換に よる計算精度の低下はない。

（3）対称性が計算モデル全体で成立しない場合で も，縁付きブロック対角化法により，対称性によるモ デル縮約効果が得られる。また，その適用基準を明碓 に示した。

（4）実際のシミュレーションにより，計算精度の 低下を招くことなく，大幅に計算時間が短縮されるこ とを示した。

(平成 2 年 7 月 24 日受付，同 3 年 2 月 14 日再受付)

$$
\text { 文献 }
$$

(1) M.V. K. Chari and P. Silvester: IEEE Trans. Power Apparatus Syst., PAS-90, 2362(1971)

(2) Nitta, et al.: IEEE Trans. Magnetics, MAG-19, 2643 (1983).

（3）榎園：境界要素解析, p. 169(昭61)培風館

(4) D. C. White, et al.: Electromechanical Energy Conversion, (1950) John Wiley \& Sons

（5）前川: 二相回路の理論と三相 2 回線の送電問題(昭 44) 東京 電機大学出版局

(6) H. Tsuboi \& T. Misaki : IEEE Trans. Magnetics, MAG23, 3044 (1987)

（7）坪井・田中・美咲：電気学会静止器・高電圧研資, SA-89-33; $\mathrm{HV}-89-34$ (平元)
(8) T. Morisue, et al. : IEEE Trans. Magnetics, MAG-24, 106 (1988)

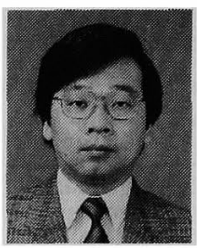

坪井始 (正員)

昭和 27 年 4 月 23 日生。 53 年 3 月岡山大学大学院工学研究科電気工 学専攻修士課程修了。同年 4 月同大 学工学部電気工学科助手。61 年 7 月同助教授, 平成 2 年 10 月福山大学工学部情報処理 工学科助教授, 3 年 4 月同教授。現在に至る。工学博 士。主として, 電子計算機による電磁界解析とその電 気・電子機器の最適設計への応用に関する研究に従事。

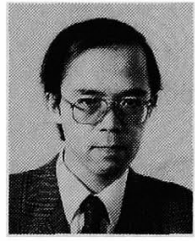

内 藤 督（正員）

昭和 23 年 2 月 21 日生。 48 年 3 月新潟大学大学院修士課程修了。同 年 4 月富士電機 (株) 入社。現在に至 る。工学博士。この間, 主として温 度上昇, 電磁界の解析法, 高圧配電系統の転流振動の 解析法および抑制法などに関する研究に従事。

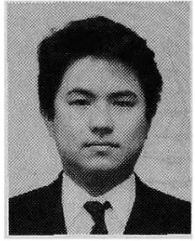

桜 井章広 (准員)

昭和 41 年 2 月 18 日生。平成元年 3 月岡山大学工学部電気工学科卒 業。3 年 3 月同大学大学院工学研究 科電気工学専攻修士課程修了。現 在, 住友電気工業(株)に勤務。在学中は電子計算機に よる三次元電磁界解析の研究に従事。 